\title{
PARTISIPASI MASYARAKAT DALAM PENYELENGGARAAN PENDIDIKAN PADA SEKOLAH MENENGAH PERTAMA NEGERI DI KECAMATAN SIRIMAU KOTA AMBON
}

\author{
RIVALDO PAUL TELUSSA
}

Dosen Universitas Satya Wiyata Mandala Nabire email.rivaldopaultelussa@yahoo.com

\section{ARTICLE INFO}

\section{Article History:}

Accepted 1 September 2019

Available Online 18 Oktober 2019

\section{Keywords:}

Partisipasi Masyarakat, Penyelenggaraan Pendidikan, Sekolah Menengah Pertama.

\section{ABSTRACT}

Tujuan penelitian ini adalah untuk 1) mengetahui bentuk-bentuk partisipasi masyarakat, 2) mengetahui pengelolaan partisipasi masyarakat, 3) mengetahui faktor penghambat partisipasi masyarakat dan 4) mengetahui upaya sekolah dalam meningkatkan partisipasi masyarakat. Penelitian dilakukan di SMP Negeri di Kecamatan Sirimau Kota Ambon dari bulan Maret-Juni 2018. Objek penelitian berjumlah 12 orang.

Metode yang digunakan adalah metode kualitatif. Teknik pengumpulan data menggunakan wawancara dan dokumentasi. Teknik instrumen pengumpulan data menggunakan pedoman wawancara dan studi dokumentasi. Keabsahan data menggunakan triangulasi sumber, triangulasi teknik. Analisis data menggunakan Miles dan Huberman dengan langkah-langkah yaitu pengumpulan data, reduksi data, penyajian data dan penarikan kesimpulan.

Hasil penelitian menunjukkan bentuk partisipasi tenaga dan material tidak terlihat di SMP Negeri 4, sedangkan bentuk tenaga, finansial, material, ide dan gagasan terlihat di keempat SMP Negeri. Dalam perencanaan, 
pelaksanaan, monitoring dan evaluasi program dari keempat SMP Negeri terlihat. Faktor penghambat partisipasi pada keempat SMP Negeri adalah finansial dan waktu. Upaya meningkatkan partisipasi yang dilakukan dari keempat SMP Negeri yaitu terlihat dengan keterlibatan orang tua dan komite sekolah.

\section{PENDAHULUAN}

Masyarakat memiliki potensi-potensi yang dapat didayagunakan dalam mendukung program-program sekolah. Untuk itu agar sekolah dapat tumbuh dan berkembang, maka program sekolah harus sejalan dengan kebutuhan masyarakat.

Partisipasi masyarakat sebagai bagian yang penting dalam penyelenggaraan pendidikan nasional memang sudah cukup jelas sebagaimana dalam Undang-Undang Sistem Pendidikan Nasional pasal 15 yang menyatakan bahwa pendidikan merupakan tanggung jawab bersama antara keluarga, masyarakat dan pemerintah yang berlaku pula dalam hal biaya, maka hal yang perlu mendapat perhatian kaitannya dengan pelibatan (partisipasi) masyarakat agar sesuai dengan harapan demi terwujudnya kualitas pendidikan yang tinggi adalah membangun suatu strategi yang dapat digunakan untuk menumbuhkembangkan partisipasi masyarakat agar dapat dimanfaatkan secara optimal dalam upaya peningkatan kualitas pendidikan.

Partisipasi masyarakat dan orang tua di sekitarnya sangat penting. Di satu sisi sekolah memerlukan masukan dari masyarakat dalam menyusun program relevan, sekaligus memerlukan bantuan dan dukungan dari masyarakat dalam melaksanakan program tersebut. Dilain pihak, masyarakat memerlukan jasa sekolah untuk mendapatkan program-program pendidikan yang sesuai dengan yang diinginkan. Jalinan semacam itu dapat saling melengkapi untuk meningkatkan mutu penyelenggaraan pendidikan di tingkat sekolah. Pada akhirnya apabila partisipasi telah terpelihara dengan baik, maka sekolah tidak akan mengalami kesulitan yang berarti dalam mengembangkan berbagai jenis program, karena semua pihak telah memahami dan merasa bertanggung jawab terhadap keberhasilan suatu program yang akan dikembangkan oleh pihak sekolah.

Dengan sendirinya agar semua terpelihara dengan baik, maka harus ada komunikasi timbal balik antara sekolah dengan semua pihak yang berkepentingan, terutama masyarakat setempat dan orang tua peserta didik sehingga sekolah, masyarakat dan orang tua menjadi satu kesatuan yang utuh dalam menyelenggarakan proses pendidikan yang bermutu di sekolah. 


\section{METODE}

Jenis penelitian yang digunakan dalam penelitian ini adalah jenis kualitatif. Penelitian ini dilakukan pada SMP Negeri 4 Ambon, SMP Negeri 6 Ambon, SMP Negeri 10 Ambon dan SMP Negeri 14 Ambon dengan waktu penelitian itu dari MaretJuni 2018. Sumber data penelitian yaitu kepala sekolah, ketua komite sekolah dan salah satu orang tua siswa.

Pengumpulan data dilakukan dengan menggunakan teknik wawancara dan dokumentasi. Data yang diperoleh kemudian dianalisis dengan menggunakan langkahlangkah yaitu pengumpulan data, reduksi data, penyajian data dan penarikan kesimpulan.

\section{HASIL PENELITIAN}

\section{Bentuk-Bentuk Partisipasi Masyarakat}

Bentuk-bentuk partisipasi masyarakat dalam penyelenggaraan pendidikan pada Sekolah Menengah Pertama di Kecamatan Sirimau Kota Ambon yang meliputi partisipasi bentuk tenaga pada SMP Negeri 4 Ambon tidak ada partisipasi bentuk tenaga. Dalam setiap pekerjaan pembangunan itu pihak sekolah hanya menyewa tukang bangunan saja. Pada SMP Negeri 6 Ambon, SMP Negeri 10, dan SMP Negeri 14 Ambon untuk sumbangan tenaga ini diberikan oleh orang tua siswa yang mempunyai kemampuan dan keahlian saja. Untuk sumbangan finansial ini barik dari SMP Negeri 4 Ambon, SMP Negeri 6 Ambon, SMP Negeri 10 Ambon dan SMP) Negeri 14 Ambon orang tua siswa memberikan sumbangan sukarela tanpa paksaan yang diberikan sesuai dengan kemampuan ekonomi mereka. Adapun bentuk sumbangan material yang diberikan dari orang tua siswa pada SMP Negeri 4 Ambon itu tidak ada, tetapi pada SMP Negeri 6 Ambon ada orang tua siswa memberikan buku pelajaran dan mebeler untuk pembuatan pojok baca, SMP Negeri 10 Ambon ada sumbangan komputer dari alumni dan pemberian biola dari Prof Dr Jhon Pieris dan SMP Negeri 14 Ambon orang tua siswa memberikan semen dan batu untuk pembuatan pojok baca dan lapangan olahraga. Untuk sumbangan ide dan gagasan pada SMP Negeri 4 Ambon ini masuan yang diberikan itu bersifat membangun dan meningkatkan prestasi akademik maupun non akademik, sedangkan pada SMP Negeri 6 Ambon masukan yang disampaikan oleh orang tua siswa itu pembuatan pojok baca dengan tujuan dapat dimanfaatkan oleh siswa selama jam istirahat maupun jam pelajaran yang kosong. Pada SMP Negeri 10 Ambon masukan yang disampaikan dari orang tua siswa itu hanya tentang pengembangan sekolah dan pada SMP Negeri 14 Ambon masukan yang disampaikan itu sekolah harus perhatikan jadwal les tambahan karena siswa juga harus istirahat dan juga program tuntas Alquran. 


\section{Pengelolaan Partisipasi Masyarakat}

Adapun dalam perencanaan program sekolah di SMP Negeri 4 Ambon orang tua siswa dan komite sekolah dilibatkan dan ditentukan program-program sekolah yang sesuai dengan kebutuhan sekolah yaitu ekstrakurikuler kesenian dalam hal ini permainan biola. Untuk SMP Negeri 6 Ambon perenacanaan program skeolah orang tua siswa dan komite sekolah juga diikutsertakan dan penentuan program sekolah pembuatan pojok baca itu dilakukan secara bersama-sama. Pada SMP Negeri 10 Ambon dalam perencanaan program sekolah itu orang tua siswa dan komite sekolah dilibatkan dan salah satu program sekolah mereka itu meningkatkan kemampuan para siswa dalam permainan musik totobuang dengan dilakukan kegiatan ekstrakurikuler. Adapaun pada SMP Negeri 14 Ambon penentuan program tuntas Alquran dan pembuatan pojok baca itu dilakukan secara bersama-sama dengan orang tua siswa dan juga komite sekolah dalam rapat.

Dalam implementasi program sekolah di SMP Negeri 4 Ambon orang tua siswa memberikan snack untuk siswa pada kegiatan porseni. Sedangan pada SMP Negeri 6 Ambon orang terlibat dalam program sekolah itu pada pembuatan pojok baca dimana mereka menyiapkan mebeler dan buku pelajaran. Untuk SMP Negeri 10 Ambon orang tua siswa yang mempunyai kemampuan dan keahlian dalam permainan musik totobuang mereka melatih siswa. Dan di SMP Negeri 14 Ambon orang tua siswa juga terlibat dalam kegiatan tuntas Alquran dan juga pemberian mebeler dan buku pelajaran untuk kegiatan pojok baca.

Adapun kegiatan monitoring program sekolah pada SMP Negeri 4 Ambon, SMP Negeri 6 Ambon, SMP Negeri 10 Ambon dan juga SMP Negeri 14 Ambon itu ada kunjungan ke sekolah secara langsung dari orang tua siswa. Kunjungan mereka berkunjung itu tidak menentu, jadi apabila ada orang tua siswa yang tidak mempunyai kesibukan mereka berkunjung ke sekolah untuk melihat perkembangan sekolah.

Untuk proses evaluasi program sekolah pada SMP Negeri 4 Ambon, SMP Negeri 6 Ambon, SMP Negeri 10 Ambon dan SMP Negeri 14 Ambon selalu melibatkan orang tua siswa dan juga komite sekolah. Dalam evaluasi tersebut kepala sekolah mempertanggung jawabkan pelaksanaan program dan juga anggaran sekolah selama setahun pelajaran.

\section{Faktor Penghambat Partisipasi Masyarakat}

Faktor penghambat partisispasi masyarakat dalam penyelenggaraan pendidikan di SMP Negeri 4 Ambon, SMP Negeri 6 Ambon, SMP Negeri 10 Ambon dan juga SMP Negeri 14 Ambon adalah faktor finansial dan juga faktor waktu. 


\section{Upaya Sekolah dalam Meningkatkan Partisipasi Masyarakat}

Upaya yang dilakukan pihak sekolah dalam meningkatkan partisipasi masyarakat dalam penyelenggaraan pendidikan di SMP Negeri 4 Ambon, SMP Negeri 6 Ambon, SMP Negeri 10 Ambon dan juga SMP Negeri 14 Ambon yaitu dengan menjalin komunikasi yang efektif. Komunikasi yang dijalin melalui rapat antara pihak sekolah dengan orang tua siswa. Dalam rapat tersebut membahas tentang pengembangan sekolah dan juga penentuan-penentuan program sekolah yang sesuai dengan kebutuhan siswa dan juga sekolah.

Adapun dalam melaksanakan program sekolah orang tua siswa dan juga komite sekolah selalu dilibatkan. Misalnya saja pada SMP Negeri 4 Ambon untuk kegiatan porseni orang tua siswa menyiapkan snack. Berbeda lagi dengan SMP Negeri 6 Ambon orang tua siswa terlibat dalam pembuatan taman baca yaitu dengan memberikan buku pelajaran dan juga mebelernya. Untuk SMP Negeri 10 Ambon orang tua siswa yang mempunyai bakat di bidang kesenian musik totobuang mereka melatih siswa dalam kegiatan ekstrakurikuler. Pada SMP Negeri 14 Ambon orang tua siswa terlibat dalam kegiatan tuntas Alquran.

Untuk kegiatan rapat tahunan di SMP Negeri 4 Ambon, SMP Negeri 6 Ambon, SMP Negeri 10 Ambon dan SMP Negeri 14 Ambon orang tua siswa selalu diundang dalam rapat tersebut. Dalam rapat tersebut selalu membahas tentang proses pengembangan sekolah dan peningkatan prestasi siswa dibidang akademik dan non akademik.

\section{PEMBAHASAN}

\section{Bentuk-Bentuk Partisipasi Masyarakat}

Tidak bisa dipungkiri bahwa keberhasilan pendidikan merupakan tanggung jawab kolektif antara sekolah, masyarakat dan para pemangku pementingan. Peran serta masyarakat sebenarnya bukan hanya dalam bentuk fisik saja tetapi juga dalam bentuk pikiran, bahkan juga perasaan (mental dan emosional). Peran serta masyarakat dapat dijadikan sebagai motivasi pengembangan sekolah karena melalui peran serta masyarakat pihak sekolah dapat memperoleh inspirasi untuk mengembangkan program-program akademik yang mendukung siswa untuk mencapai prestasi belajarnya (Rahman 2014: 82)

Partisipasi masyarakat sering diartikan sebagai sumbangan tenaga, uang, barang dan ide dalam rangka menyukseskan program atau proyek pembangunan di sekolah (Suryosubroto 2012 : 73). 
Untuk SMP Negeri 4 Ambon, SMP Negeri 6 Ambon, SMP Negeri 10 Ambon dan juga SMP Negeri 14 Ambon orang tua siswa sudah terlibat dan memberikan sumbangan baik itu tenaga, finansial, material serta ide dan gagasan.

\section{Pengelolaan Partisipasi Masyarakat}

Perencanaan merupakan suatu proses yang berlangsung tanpa henti, karena pada suatu saat kegiatan sudah selesai, maka kegiatan dilanjutkan dengan kegiatankegiatan berikutnya, sehingga membentuk siklus kegiatan (Frud 2014)

Perencanaan program sekolah adalah hal yang penting dalam penyelenggaraan pendidikan. Karena dari sanalah keseluruhan pelaksanaan hingga kualitas dan kompetensi dari output pendidikan ditentukan. Mengingat pendidikan adalah dari masyarakat, maka partisipasi masyarakat dalam hal ini orang tua siswa dan komite sekolah sangatlah diperlukan dalam perencanaan program sekolah.

Dalam perencanaan program sekolah di SMP Negeri 4 Ambon, SMP Negeri 6 Ambon, SMP Negeri 10 Ambon dan juga SMP Negeri 14 Ambon orang tua siswa dan komite sekolah selalu terlibat.

Partisipasi masyarakat dalam pelaksanaan program sekolah maerupakan kenjutan dari rencana yang telah disepakati sebelumnya, baik yang berkaitan dengan perencanaan, pelaksanaan maupun tujuan. Di dalam pelaksanaan program sekolah, sangatlah dibutuhkan keterlibatan semua unsur khususnya pemerintah dalam kedudukannya sebagai fokus atau sumber utama pembangunan. Menurut Ndraha dan Cohen dan Hoff dalam Siti Irene Astuti D (2009:39) ruang lingkup partisipasi dalam pelaksanaan suatu program meliputi: pertama menggerakkan sumber daya dan dana. Kedua, kegiatan administrasi dan koordinasi dan ketiga penjabaran program. Dari uraian di atas dapat disimpulkan bahwa partisipasi masyarakat dalam partisipasi pelaksaaan program satu unsur penentu keberhasilan program itu sendiri.

Dalam pelaksanaan program di SMP Negeri 4 Ambon orang tua siswa menyiapkan snack, sedangkan di SMP Negeri 6 Ambon orang tua siswa memberikan buku dan juga mebeler untuk pojok baca. Untuk SMP Negeri 10 Ambon orang tua siswa melatih siswa untuk main alat musik totobuang dan di SMP Negeri 14 Ambon orang tua siswa itu dalam kegiatan tuntas Alquran.

Monitoring merupakan proses pengumpulan data dan infromasi secara rutin untuk mengetahui perkembangan pelaksanaan program sekolah memberikan petunjuk secara dini tentang adanya masalah dan jalan keluarnya yang perlu diketahui oleh pelaksana dan membuat keputusan, tanpa memberikan penilaian apakah efektif dan efisien atau tidak.

Monitoring dilakukan untuk mengetahui perkembangan pelaksanaan program, apa hambatan yang dihadapi dan bagaimana cara mengatasi masalah tersebut. Dengan kata lain monitoring ini menekankan pada pemantauan proses pelaksanaan program dan pemberian saran untuk memperbaiki atau menyempurnakan masalah yang terjadi (Dit. SLTP Depdiknas, 2002) 
Adapun kegiatan monitoring yang dilakukan oleh orang tua siswa di SMP Negeri 4 Ambon, SMP Negeri 6 Ambon, SMP Negeri 10 Ambon dan juga SMP Negeri 14 Ambon yaitu dengan berkunjung dan melihat perkembangan sekolah secara langsung.

Dalam penyelenggaraan pendidikan, evaluasi juga merupakan hal yang sangat penting. Dari evaluasi inilah, diharapkan dapat tergambar seluruh aktivitas yang dilakukan sekolah dalam rangka menjalankan program-programnya. Lewat pelaksanaan evaluasi ini akan diketahui apa saja kelebihan dan kekurangan yang ada. Selanjutnya dicarikan tindak lanjut berupa penanggulangan dan perbaikan terhadap kekurangan-kekurangan dan pengembangan terhadap kelebihan-kelebihannya. Untuk SMP Negeri 4 Ambon, SMP Negeri 6 Ambon, SMP Negeri 10 Ambon dan SMP Negeri 14 Ambon keterlibatan orang tua siswa dan komite sekolah dalam evaluasi menjadi hal yang sangat penting karena mereka pada dasarnya objek yang membutuhkan keberadaan pendidikan. Atas dasar kebutuhan dan semangat untuk meningkatkan taraf hidup mereka maka pendidikan diselenggarakan.

Peran serta masyarakat adalah kontribusi, sumbangan dan keikutsertaan masyarakat dalam menunjang upaya peningkatan mutu pendidikan (Wuriyanto, 2007: 3). Lembaga pendidikan pada masa sekarang dalam membuat perencanaan, pelaksanaan dan monitoring pendidikan melibatkan peran serta masyarakat. Kesadaran tentang pentingnya pendidikan yang dapat memberikan harapan dan kemungkinan lebih baik di masa yang akan datang, mendorong berbagai upaya dan perhatian seluruh lapisan masyarakat. Hal inilah yang melahirkan kesadaran peran serta masyarakat.

\section{Faktor Penghambat Partisipasi Masyarakat}

Partisipasi orang tua siswa dan masyarakat dalam penyelenggaraan pendidikan sekolah sangatlah penting karena dapat mempengaruhi penyelenggaraan proses pendidikan. Mochlan dalam Suriansyah (2001) menyatakan school public relation adalah kegiatan yang dilakukan sekolah untuk memenuhi kebutuhan masyarakat.

Yang menjadi faktor penghambat partisipasi masyarakat dalam penyelenggaraan pendidikan di SMP Negeri di Kecamatan Sirimau Kota Ambon yaitu 1) Finansial, berdasarkan wawancara yang dilakukan dengan berbagai narasumber ditemukan bahwa salah satu faktor penghambar partisimasi masyarakat dalam penyelenggaraan pendidikan adalah finansial. Hal ini dikarenakan oleh tingkat ekonomi orang tua siswa di SMP Negeri 4 Ambon, SMP Negeri 6 Ambon, SMP Negeri 10 Ambon dan juga SMP Negeri 14 Ambon ini menengah ke bawah. Sehingga terkadang mereka sulit untuk terlibat langsung dalam penyelenggaraan pendidikan di sekkolah. 2) Waktu. Hasil wawancara membuktikan bahwa waktu juga menjadi faktor penghambat partisipasi masyarakat. Hal ini dikarenakan bahwa orang tua siswa itu terlalu sibuk dengan segala urusan mereka. 3) kurang adanya perhatian. Dalam wawancara terkaait dengan faktor penghambat partisipasi masyarakat dalam penyelenggaraan pendidikan ini ditemukan bahwa orang tua siswa kurang 
memperhatikan siswa. Hasil yang ditemukan bahwa orang tua siswa hanya menganggap bahwa tugas mendidik anak itu hanya seorang guru. Mereka belum menyadari bahwa tugas orang tua siswa juga mendidik anak selama dia berada di rumah. Ada juga responden yang mengatakan bahwa orang tua siswa tidak selalu memperhatikan jam-jam belajar anak dirumah, masih kurang fungsi kontrol dari orang tua siswa terhadap tugas-tugas siswa dirumah. Sehingga ketika di skeolah ada siswa yang tidak mengerjakan tugas rumah.

\section{Upaya Sekolah dalam Meningkatkan Partisipasi Masyarakat}

Kerjasama antara sekolah dan masyarakat merupakan satu pilar yang penting dalam mengatasi persoalan tersebut. Bila sudah ada jalinan kerjasama antara sekolah dengan masyarakat, maka kerjasama tersebut harus terus dibina, ditingkatkan dan dikembangkan untuk mewujudkan sekolah yang bermutu dan efektif (Tilaar 2004: 67). Sangatlah penting bagi sekolah untuk memjalankan peranan kepemimpinan yang aktif dalam menggalakan program-program sekolah melalui peran aktif orang tua dan masyarakat (Mansyur 2010).

Keikutsertaan dan kesadaran masyarakat untuk memikul tanggung jawab pendidikan bukan sekedar harapan tetapi merupakan suatu tuntutan mendesak yang harus diwujudkan dalam kegiatan-kegiatan nyata dilapangan (Benty \& Gunawan 2015)

Adapun komunikasi yang efektif antara orang tua siswa dan komite sekolah di SMP Negeri 4 Ambon, SMP Negeri 6 Ambon, SMP Negeri 10 Ambon dan SMP Negeri 14 Ambon ini adalah melalui rapat bersama. Dalam rapat tersebut hal-hal yang dibahas itu tentang peningkatan prestasi akademik dan non akademik. Selanjutnya untuk melibatkan orang tua siswa dan komite sekolah di SMP Negeri 4 Ambon mereka menyiapkan snack untuk kegiatan porseni. Untuk SMP Negeri 6 Ambon mereka memberikan buku pelajaran dan juga mebeler untuk pembuatan pojok baca, sedangkan untuk SMP Negeri 10 Ambon orang tua siswa memberikan latihan dalam kegiatan ekstrakurikuler kesenian alat musik totobuang kepada siswa dan di SMP Negeri 14 Ambon mereka terlibat dalam kegiatan tuntas Alquran.

Untuk kegiatan rapat tahunan orang tua siswa dan komite sekolah di SMP Negeri 4 Ambon, SMP Negeri 6 Ambon, SMP Negeri 10 Ambon dan SMP Negeri 14 Ambon selalu dilibatkan. Dalam rapat tersebut berbicara tentang pengembangan sekolah.

\section{KESIMPULAN}

Berdasarkan hasil temuan penelitian dan pembahasan, dapat ditarik kesimpulan sebagai berikut: (1) bentuk partisipasi masyarakat berupa bantuan tenaga ada pekerjaan renovasi sekolah dan pembuatan lapangan olahraga. Bentuan berupa finansial itu adalah sumbangan sukarela tanpa paksaan. Sumbangan tersebut dapat dilakukan untuk semua kebutuhan sekolah. bnatuan berupa material itu ada yang memberikan sumbangan pasir, semen, komputer, biola, buku dan juga mebeler untuk kebutahan 
sekolah. sumbangan bentuk ide dan gagasan itu terkait dengan pengembangan sekolah. (2) pengelolaan partisipasi masyarakat yang terkait dengan perencanaan program sekolah bahwa orang tua siswa dan komite sekolah selalu dilibatkan dalam penentuan program sekolah yang sesuai dengan kebutuhan sekolah. Untuk implementasi program sekolah ada orang tua siswa yang memberikan snack untuk kegiatan porseni, ada juga yang memberikan buku pelajaran dan mebeler untuk pojok baca, ada yang melatih siswa untuk main musik totobuang dan juga ada yang ikut dalam kegiatan tuntas Alquran. Terkait dengan kegiaatan monitoring di sekolah itu orang tua siswa dan juga komite sekolah yang tidak ada kesibukan mereka berkunjung ke sekolah untuk melihat perkembangan sekolah. Selanjutnya untuk evaluasi program sekolah orang tua siswa dan komite sekolah juga dilibatkan. Dalam kegiatan tersebut kepala sekolah mempertanggung jawabkan pelaksanaan program sekolah dan penggunaan anggaran sekolah. (3) untuk faktor yang menghambat partisipasi masyarakat adalah finansial karena tingkat pendapatan orang tua siswa itu menengah ke bawah. Dan juga mengenai tingkat kepedulian orang tua terhadap anak, terkadang orang tua siswa tidak terlalu pedulu dengan pendidkan anak selama disekolah. Mereka beranggapan bahawa tugas untuk mendidik anak hanya guru disekolah. (4) upaya untuk meningkatkan partisipasi masyarakat bentuknya menjalin komunikasi yang efektif dengan orang tua siswa dan juga komite sekolah lewat rapat yang dilakukan oleh pihak sekolah. Selanjutnya juga melibatkan orang tua siswa dalam program sekolah. Ada orang tua siswa yang memberikan snack untuk porseni, menyiapkan mebeler dan buku pelajaran untuk pojok baca, ikut melatih siswa untuk bermain alat musik totobuang dan terlibat dalam kegiatan tuntas Alquran. Untuk rapat tahunan di sekolah itu orang tua siswa dan juga komite sekolah dilibatkan dan dalam rapat tersebut selalu membahas tentang peningkatan prestasi siswa dibidang akademik dan non akademik.

\section{DAFTAR PUSTAKA}

Benty, N.D.D \& Gunawan, I. 2015. Manajemen Hubungan Sekolah dan Masyarakat. UM Press. IKIP Malang

Bogdan C. Robert dan Sari Knopp Biklen. 2007. Qualitative Reseach For Education An Introduction To Theories and Method. Boston Syaracuse University, Pearson)

Depdiknas. 2005. Acuan Operasional dan Indikator Kinerja Komite Sekolah. Jakarta: Ditmandiknasmen. Depdiknas.

Depdikbud. 2002. Panduan Monitoring dan Evaluasi. Jakarta: Dit.PLP Ditjen Dikdasmen Depdiknas

Mansyur. 2010. Strategi Membangun Partisipasi Masyarakat Terhadap Pendidikan Islam. (online), http://bdkbanjarmasin.kemenag.go.id. Diakses pada tanggal 10 Jauari 2015 
Moleong, Lexy, J. 2007. Metodologi Penelitian Kualitatif Edisi Revisi. Bandung : PT Ramaka Rosdakarya Offset

Siti Irene Astuti D. 2009. Desentralisasi dan Partisipasi dalam Pendidikan. Yogyakarta: UNY

Sugiyono. 2007. Metode Penelitian Pendidikan Pendekatan Kuantitatif, Kualitatif, dan $R \& D$. Bandung: Alfabeta.

Suriansyah, A. 2001. Hubungan Sekolah Dengan Masyarakat. Diktat Bahan Kuliah pada Program Studi Administrasi Pendidikan, FKIP Unlam. Banjarmasin: FKIP Unlam

Suryosubroto. 2001. Humas Dalam Dunia Pendidikan. Yogyakarta: Mitra Gama Widya.

Tilaar, H.A.R. 2004. Paradigma Baru, Pendidikan Nasional. Jakarta: PT Rineka Cipta.

Warren, M., Hong, S., Rubin, C., \& Uy, P. 2009. Beyond the bake sale: A communitybased relation approach to parent engagement in school. The Teacher College Record, 111 (9), 2209-2252.

Wuriyanto, A.B. 2007. Peran Serta Masyarakat, (online), (http:unila.ac.id. diakses 8 Januari 2013) 